\title{
Do separated taxa react differently to a long-term salinity increase? The meiobenthos changes in Bay Sivash, largest hypersaline lagoon worldwide
}

\author{
Nickolai Shadrin ${ }^{1}$, Elena Kolesnikova ${ }^{1}$, Tatiana Revkova ${ }^{1}$, Alexander Latushkin ${ }^{2}$, Anna Chepyzhenko ${ }^{2}$, \\ Inna Drapun ${ }^{1}$, Nikolay Dyakov ${ }^{3}$, and Elena Anufriieva ${ }^{1, *}$ \\ ${ }^{1}$ A.O. Kovalevsky Institute of Biology of the Southern Seas of RAS, 2 Nakhimov av., 299011 Sevastopol, Russia \\ 2 Marine Hydrophysical Institute, Russian Academy of Sciences, 2 Kapitanskaya St., 299011 Sevastopol, Russia \\ ${ }^{3}$ Sevastopol Branch of the N.N. Zubov State Oceanographic Institute, 61 Sovetskaya St., 299011 Sevastopol, Russia
}

Received: 31 May 2019 / Accepted: 29 July 2019

\begin{abstract}
In the world's largest hypersaline lagoon Bay Sivash, its ecosystem twice transformed from a previous state to a new one due to human intervention. Before the North Crimean Canal construction, it was hypersaline (average salinity of $140 \mathrm{~g} \mathrm{l}^{-1}$ ). The canal was built between 1963 and 1975, which resulted in intensive development of irrigated agriculture discharging drainage water into the bay. Between 1988 and 2013, salinity gradually dropped to average of $18-23 \mathrm{~g} \mathrm{l}^{-1}$; a new ecosystem with a different biotic composition formed. In April 2014, the supply of Dnieper water into the North Crimean Canal ceased. This resulted in a gradual salinity increase in the bay to an average of $52 \mathrm{~g} \mathrm{l}^{-1}$ in 2015 . The start of second ecosystem shift was observed in 2015. In 2018, TSS, DOM and meiobenthos were studied in a salinity gradient from 30 to $88 \mathrm{~g} \mathrm{l}^{-1}$. There was an increase in TSS and DOM with increasing salinity. The meiobenthos structure was significantly different in the bottom community and floating mats of filamentous green algae. No correlation was recorded between the number of meiobenthic macrotaxa in the sample and salinity. From 2013 to 2018, changes were seen in the taxocene structure of Nematoda and Harpacticoida. Changes in Nematoda were more dramatic and prolonged than in Harpacticoida. The structure of the Harpacticoida and Ostracoda taxocenes are less variable and more stable than that of the Nematoda taxocene. One of the reasons may be more mobility of Harpacticoida/ Ostracoda than Nematoda and/or better osmoadaptation mechanisms.
\end{abstract}

Keywords: Lagoons / long-term changes / hypersaline / meiobenthos / anthropogenic impact

Résumé - Des taxons différents réagissent-ils différemment à une augmentation de la salinité à long terme ? Le meiobenthos change à Bay Sivash, le plus grand lagon hypersalin du monde. Dans la plus grande lagune hypersaline du monde, la baie de Sivash, son écosystème s'est transformé à deux reprises d'un état antérieur à un nouvel état grâce à l'intervention humaine. Avant la construction du canal de Crimée-Nord, il était hypersalin (salinité moyenne de $140 \mathrm{~g} \mathrm{l}^{-1}$ ). Le canal a été construit entre 1963 et 1975 , ce qui a entraîné un développement intensif de l'agriculture irriguée et le déversement des eaux de drainage dans la baie. Entre 1988 et 2013, la salinité est progressivement tombée à une moyenne de $18-23 \mathrm{~g} \mathrm{l}^{-1}$; un nouvel écosystème avec une composition biotique différente s'est formé. En avril 2014, l'approvisionnement en eau du Dniepr dans le canal de Crimée-Nord a cessé. Il en a résulté une augmentation graduelle de la salinité dans la baie, qui a atteint une moyenne de $52 \mathrm{~g} \mathrm{l}^{-1}$ en 2015 . Le début du deuxième changement d'écosystème a été observé en 2015. En 2018, le TSS, le DOM et le meiobenthos ont été étudiés dans un gradient de salinité de 30 à $88 \mathrm{~g}^{-1}$. Il y a eu une augmentation des SCT et des DOM avec l'augmentation de la salinité. La structure du meiobenthos était très différente dans la communauté du fond et dans les tapis flottants d'algues vertes filamenteuses. Aucune corrélation n'a été enregistrée entre le nombre de macrotaxa meiobenthiques dans l'échantillon et la salinité. De 2013 à 2018, des changements ont été observés dans la structure taxocène de Nematoda et Harpacticoida. Les changements de Nematoda ont été plus spectaculaires et prolongés que ceux des Harpacticoida. La structure des taxocènes Harpacticoida et

\footnotetext{
*Corresponding author: lena_anufriieva@mail.ru
} 
Ostracoda est moins variable et plus stable que celle du taxocène Nematoda. Une des raisons peut être une plus grande mobilité des Harpacticoida/Ostracoda que des Nematoda et/ou de meilleurs mécanismes d'osmoadaptation.

Mots-clés : lagunes / changements à long terme / hypersaline / meiobenthos / impact anthropogénique

\section{Introduction}

Salinity is an important factor influencing biotic and abiotic structure and processes in aquatic ecosystems (Segal et al., 2006; Jordan et al., 2008; Telesh and Khlebovich, 2010; Shadrin, 2018; Mayer and Pilson, 2019). The salinity changes lead to transformations of taxonomic composition in marine and continental waters. These changes occur due to global climate fluctuations and various anthropogenic impacts or their interaction (Suzuki et al., 1998; Ferrarin and Umgiesser, 2005; Riera et al., 2011; Shadrin and Anufriieva, 2013; Micklin et al., 2016; Shadkam et al., 2016; El-Shabrawy et al., 2018; Ghale et al., 2018; Golubkov et al., 2018; Lockwood, 2019). Among the anthropogenic causes, the discharge of hypersaline brine from desalination plants increases around the world; currently 15,906 operational plants produce brine of around 142millionm ${ }^{-3}$ day $^{-1}$ (Jones et al., 2019). In the world, there are a lot of natural hypersaline lakes and lagoons. Ongoing salinity rising, caused by all factors mentioned above, multiplies their number along with significant reduction and transformation of their biodiversity (Riera et al., 2011; Micklin et al., 2016; Shadrin et al., 2018). The effects of salinity on species richness and composition in zooplankton and macrozoobenthos have been studied (Filippov and Komendantov, 1995; Schallenberg and Burns, 2003; Mageed, 2006; Carrasco and Perissinotto, 2012; Shadrin and Anufriieva, 2013; El-Shabrawy et al., 2015; Micklin et al., 2016), but there has been little study on the meiobenthos in hypersaline waters and its changes to during a salinity increase (Olafsson et al., 2000; De Lomas et al., 2005; Kolesnikova et al., 2008, 2017; Mokievsky, 2009; Sergeeva et al., 2019). The meiobenthos is an important functional component of aquatic ecosystems, and its average share in total production of benthic animals is about 60\% (Mokievsky, 2009). The contribution of the meiobenthos to species richness, biomass and production of the benthic community grows with increasing habitat stress (Levin et al., 2009; Shadrin et al., 2018; Zeppilli et al., 2018). Meiobenthic animals dwell in habitats completely lacking larger metazoans (Giere, 1993). There is no doubt that changes in the structure of the meiobenthos affect the functioning of other components of aquatic ecosystems (Mokievsky, 2009; Carugati et al., 2018). Therefore, the meiobenthos can be one of the most effective bioindicators of an aquatic environment state (Gyedu-Ababio and Baird, 2006; Moreno et al., 2008; Riera et al., 2011; Alves et al., 2013; Semprucci et al., 2015; Zeppilli et al., 2018; Carugati et al., 2018). The meiobenthos may supply information of great bioindication interest not only due to its valuable role in marine food chains but also due to its ecological characteristics (small size of animals, high abundance, high generation rates and sensitivity to variations in environmental situation). Therefore, this paper is focused on the meiobenthic changes under a salinity increase.

The world's largest hypersaline lagoon Bay Sivash (the Sea of Azov) is also the largest lagoon in Europe. It is separated from the Sea of Azov by the narrow sand Arabat Spit which is $112-116 \mathrm{~km}$ long (Fig. 1). It covers $2560 \mathrm{~km}^{2}$, and the narrow Henichesk Strait connects it with the sea on the north (Vorobyev, 1940; Shadrin et al., 2018). Before the construction of the North Crimean Canal, it was a semi-closed, shallow, highly productive hypersaline lagoon with many spits, islands, bars and depressions with salt-marshes and small salt pools in the area of the lagoon and adjoining area. Average salinity was of $140 \mathrm{~g} \mathrm{l}^{-1}$, in the southern part - up to $>200 \mathrm{~g} \mathrm{l}^{-1}$ (Vorobyev, 1940; Shadrin et al., 2018). Construction of the North-Crimean Canal (1963-1975) changed everything. From 1963, water from the Dnieper River began to flow into the canal which was used for irrigation, and drainage water from irrigated fields began to discharge to the lagoon. As a result, the average salinity in the bay decreased to $17.0-22.6 \mathrm{~g} \mathrm{l}^{-1}$ in $1989-1997$, and a new brackish water ecosystem formed (Shadrin et al., 2018). In April 2014, it was decided to cut off the supply of Dnieper water to the North-Crimean Canal. The discharge of fresh water into the lagoon from agricultural fields practically ceased. A study conducted in 2015 showed that salinity increased in the Bay fluctuating between 28 and $75 \mathrm{~g} \mathrm{l}^{-1}$ in 2015 (Shadrin et al., 2018). A new ecosystem transformation had begun in the lagoon with changes occurring in all ecosystem components including the meiobenthos (Drapun et al., 2017; Kolesnikova et al., 2017; Shadrin et al., 2018; Sergeeva et al., 2019). From 2015, filamentous green algae Cladophora siwaschensis $\mathrm{C}$. Meyer again formed floating mats with biomass (ww) up to $2.5-3.0 \mathrm{~kg} \mathrm{~m}^{-2}$ and which occupy large areas in the bay; hypoxic and even anoxic conditions often occur beneath them (Drapun et al., 2017; Shadrin et al., 2018).

The goals of this paper are to provide new data obtained in 2018 to compare with published data; to analyze the long-term trends of the meiobenthic changes in Bay Sivash; and to verify or disprove a hypothesis that the long-term trends of the changes in Nematoda and Harpacticoida are different.

\section{Materials and methods}

Samples were collected in May and June 2018 during two expeditions (Fig. 1, Tab. 1). The authors used the same methods as previously (Shadrin et al., 2018; Sergeeva et al., 2019), briefly described here. Meiobenthic samples were collected by benthic tubes (a diameter of $5 \mathrm{~cm}$ ) at the points with depths of $0.2-0.6 \mathrm{~m}$. In the floating mats of filamentous green algae, samples were taken from an area of $0.25 \mathrm{~m}^{2}$. All samples were fixed by $4 \%$ formaldehyde and analyzed under binocular MBS-9 using a Bogorov chamber. To measure the total weight of algal mat samples, the authors used an electronic balance. The number of counted animals was divided on mass of an analyzed sample to evaluate total abundance of animals per unit of mat biomass. The biophysical complex 'Condor' (produced by Akvastandart-Yug, Sevastopol, Russia) was used to determine the concentration of total 


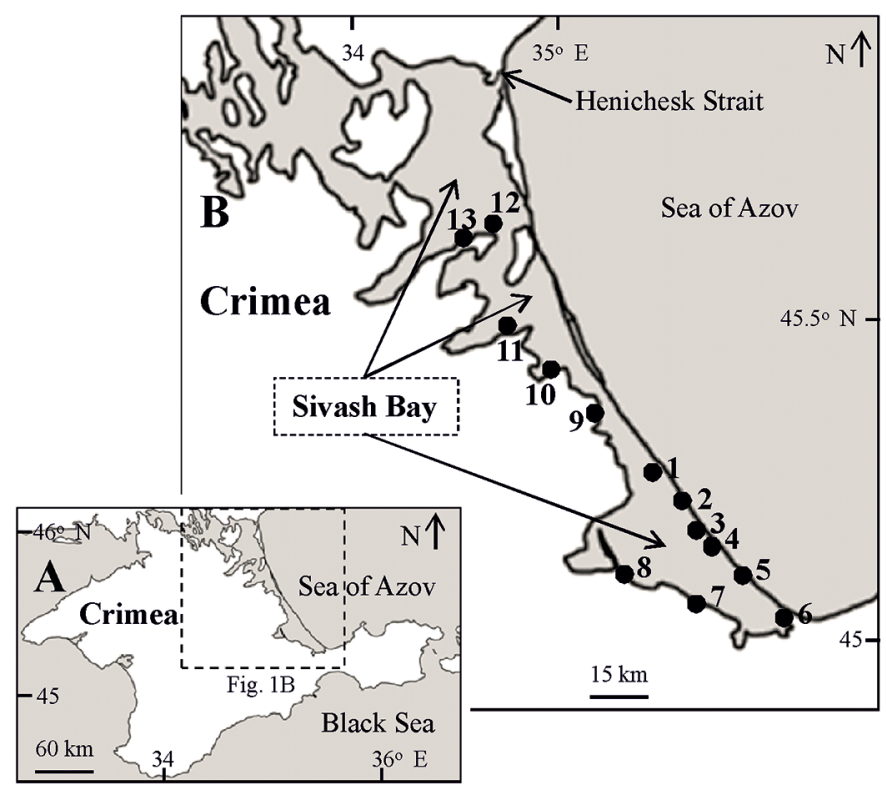

Fig. 1. Sampling stations in Sivash Bay.

Table 1. Studied characteristics in different sampling sites of Bay Sivash in May-June, 2018.

\begin{tabular}{|c|c|c|c|c|c|c|c|c|c|c|}
\hline \multirow[t]{2}{*}{ Station } & \multicolumn{2}{|c|}{ Coordinates } & \multirow[t]{2}{*}{$\begin{array}{l}\text { Salinity, } \\
\mathrm{g} 1^{-1}\end{array}$} & \multirow[t]{2}{*}{$\begin{array}{l}\text { Temperature, } \\
{ }^{\circ} \mathrm{C}\end{array}$} & \multirow[t]{2}{*}{$\begin{array}{l}\mathrm{TSS}, \\
\mathrm{mg}^{-1}\end{array}$} & \multirow[t]{2}{*}{$\begin{array}{l}\text { DOM, } \\
{\mathrm{mg} 1^{-1}}^{-1}\end{array}$} & \multicolumn{2}{|c|}{$\begin{array}{c}\text { Number of species } \\
\text { on bottom }\end{array}$} & \multicolumn{2}{|c|}{$\begin{array}{c}\text { Number of species } \\
\text { in mats }\end{array}$} \\
\hline & Latitude & Longitude & & & & & Harpacticoida & $\overline{\text { Nematoda }}$ & Harpacticoida & $\overline{\text { Nematoda }}$ \\
\hline \multicolumn{11}{|c|}{ 14-15 May } \\
\hline 1 & $45^{\circ} 31^{\prime} 13.7^{\prime \prime} \mathrm{N}$ & $35^{\circ} 11^{\prime} 12.9^{\prime \prime} \mathrm{E}$ & 76 & 21.0 & $16.95^{\circ}$ & 4.16 & 1 & 11 & 1 & 6 \\
\hline 2 & $45^{\circ} 29^{\prime} 04.7^{\prime \prime} \mathrm{N}$ & $35^{\circ} 13^{\prime} 27.9^{\prime \prime} \mathrm{E}$ & 77 & 20.0 & 16.59 & 3.97 & - & - & - & - \\
\hline 3 & $45^{\circ} 27^{\prime} 19.5^{\prime \prime} \mathrm{N}$ & $35^{\circ} 14^{\prime} 54.1^{\prime \prime} \mathrm{E}$ & 77 & 20.0 & 23.15 & 3.68 & 2 & 2 & 1 & 1 \\
\hline 4 & $45^{\circ} 24^{\prime} 43.5^{\prime \prime} \mathrm{N}$ & $35^{\circ} 17^{\prime} 33.8^{\prime \prime} \mathrm{E}$ & 77 & 20.0 & 24.20 & 3.73 & - & - & - & - \\
\hline 5 & $45^{\circ} 23^{\prime} 04.7^{\prime \prime} \mathrm{N}$ & $35^{\circ} 19^{\prime} 44.6^{\prime \prime} \mathrm{E}$ & 77 & 20.0 & 20.81 & 4.09 & 1 & 2 & 1 & 1 \\
\hline 6 & $45^{\circ} 17^{\prime} 14.3^{\prime \prime} \mathrm{N}$ & $35^{\circ} 28^{\prime} 01.2^{\prime \prime} \mathrm{E}$ & 82 & 19.5 & 12.20 & 3.80 & 2 & 3 & 1 & 3 \\
\hline 7 & $45^{\circ} 19^{\prime} 05.5^{\prime \prime} \mathrm{N}$ & $35^{\circ} 14^{\prime} 59.8^{\prime \prime} \mathrm{E}$ & 75 & 21.0 & 18.56 & 4.12 & 0 & 0 & - & - \\
\hline 8 & $45^{\circ} 21^{\prime} 04.2^{\prime \prime} \mathrm{N}$ & $35^{\circ} 06^{\prime} 06.5^{\prime \prime} \mathrm{E}$ & 75 & 20.0 & 24.76 & 4.13 & - & - & - & - \\
\hline 9 & $45^{\circ} 37^{\prime} 48.3^{\prime \prime} \mathrm{N}$ & $35^{\circ} 01^{\prime} 54.8^{\prime \prime} \mathrm{E}$ & 56 & 23.0 & 5.64 & 3.21 & 3 & 2 & 2 & 2 \\
\hline 10 & $45^{\circ} 40^{\prime} 48.8^{\prime \prime} \mathrm{N}$ & $34^{\circ} 54^{\prime} 55.2^{\prime \prime} \mathrm{E}$ & 52 & 24.5 & 3.50 & 2.93 & 1 & 0 & 1 & 4 \\
\hline 11 & $45^{\circ} 44^{\prime} 00.8^{\prime \prime} \mathrm{N}$ & $34^{\circ} 48^{\prime} 10.3^{\prime \prime} \mathrm{E}$ & 39 & 26.0 & 5.53 & 2.90 & - & - & - & - \\
\hline 12 & $45^{\circ} 52^{\prime} 38.8^{\prime \prime} \mathrm{N}$ & $34^{\circ} 44^{\prime} 33.3^{\prime \prime} \mathrm{E}$ & 36 & 25.0 & 3.11 & 3.01 & - & - & - & - \\
\hline 13 & $45^{\circ} 52^{\prime} 42.6^{\prime \prime} \mathrm{N}$ & $34^{\circ} 42^{\prime} 09.0^{\prime \prime} \mathrm{E}$ & 30 & 23.0 & 2.37 & 2.66 & 2 & 6 & 2 & 3 \\
\hline \multicolumn{11}{|c|}{ 19-20 June } \\
\hline 4 & $45^{\circ} 24^{\prime} 43.5^{\prime \prime} \mathrm{N}$ & $35^{\circ} 17^{\prime} 33.8^{\prime \prime} \mathrm{E}$ & 74 & 25 & - & - & 2 & 0 & - & - \\
\hline 5 & $45^{\circ} 23^{\prime} 04.7^{\prime \prime} \mathrm{N}$ & $35^{\circ} 19^{\prime} 44.6^{\prime \prime} \mathrm{E}$ & 69 & 24 & - & - & 1 & 1 & - & - \\
\hline 6 & $45^{\circ} 17^{\prime} 14.3^{\prime \prime} \mathrm{N}$ & $35^{\circ} 28^{\prime} 01.2^{\prime \prime} \mathrm{E}$ & 88 & 28 & - & - & 2 & 3 & - & - \\
\hline
\end{tabular}

- No sampling.

suspended solids (TSS), dissolved organic matter (DOM) and salinity. In the field, salinity was also measured using a manual refractometer Kellong WZ212, and temperature by an electronic thermometer PHH-830.

The authors calculated average values, standard deviations, coefficients of variation $(\mathrm{CV})$, correlation $(R)$ and determination $\left(R^{2}\right)$, as well as parameters of the regression equations in the standard program MS Excel 2007, and the confidence level (p) of correlation coefficients by (Müller et al., 1979). The authors used the similarity indices of Jaccard and Czekanowski-Sørensen-Dice to compare species composition in different years and biotopes (Pesenko, 1982). The thresholds to conclude the similarity of the species composition was 0.42 (Jaccard coefficient) and 0.59 (Czekanowski-Sørensen-Dice coefficient) (Shadrin et al., 2018). To calculate accumulation curves with different orderings of the samples, random permutations of data were made on-line (http://www.webcal culator.co.uk/statistics/rpermute3.htm). 
Table 2. Long-term changes of the general meiobenthic characteristics in Bay Sivash (2013-2018).

\begin{tabular}{|c|c|c|c|c|c|c|c|c|c|c|}
\hline \multirow[t]{2}{*}{ Year } & \multirow[t]{2}{*}{$\mathrm{S}, \mathrm{g} \mathrm{l}^{-1}$} & \multicolumn{3}{|c|}{ Meiobenthos } & \multicolumn{2}{|r|}{ Nematoda } & \multicolumn{2}{|r|}{ Harpacticoida } & \multirow[t]{2}{*}{$\mathrm{N} / \mathrm{M}, \%$} & \multirow[t]{2}{*}{$\mathrm{H} / \mathrm{M}, \%$} \\
\hline & & $\mathrm{FO}, \%$ & $\begin{array}{l}\text { Average abundance, } \\
\text { ind. } \mathrm{m}^{-2} / \mathrm{CV}\end{array}$ & $\mathrm{K}$ & $\mathrm{FO}, \%$ & $\begin{array}{l}\text { Average abundance, } \\
\text { ind. } \mathrm{m}^{-2} / \mathrm{CV}\end{array}$ & FO, $\%$ & $\begin{array}{l}\text { Average abundance, } \\
\text { ind. } \mathrm{m}^{-2} / \mathrm{CV}\end{array}$ & & \\
\hline \multicolumn{11}{|c|}{ Soft bottom sediments } \\
\hline 2013 & 22 & 100 & $227401 / 1.43$ & 8 & 100 & $134198 / 2.53$ & 100 & $92977 / 1.40$ & 59 & 41 \\
\hline 2015 & 52 & 100 & $1546169 / 0.65$ & 8 & 100 & $673787 / 0.58$ & 83 & $437021 / 0.63$ & 44 & 28 \\
\hline $2017 *$ & 70 & 100 & $273000 / 0.29$ & 6 & 50 & - & 75 & - & - & - \\
\hline 2018 & 69 & 91 & $264847 / 1.23$ & 7 & 73 & $97825 / 2.62$ & 91 & $57719 / 1.72$ & 37 & 22 \\
\hline \multicolumn{11}{|c|}{ Mats of filamentous green algae Cladophora } \\
\hline 2018 & 69 & 100 & $327107 / 1.29$ & 5 & 100 & $134555 / 1.41$ & 100 & $149885 / 1.96$ & 41 & 46 \\
\hline
\end{tabular}

$\mathrm{S}$ - average salinity; FO - frequency of occurrence; CV - coefficient of variability; $\mathrm{K}$ - number of meiobenthic macrotaxa; N/M contribution of Nematoda in average total abundance of meiobenthos; H/M - contribution of Harpacticoida in average total abundance of meiobenthos; 2017* - data from Soloveva et al. (2019).
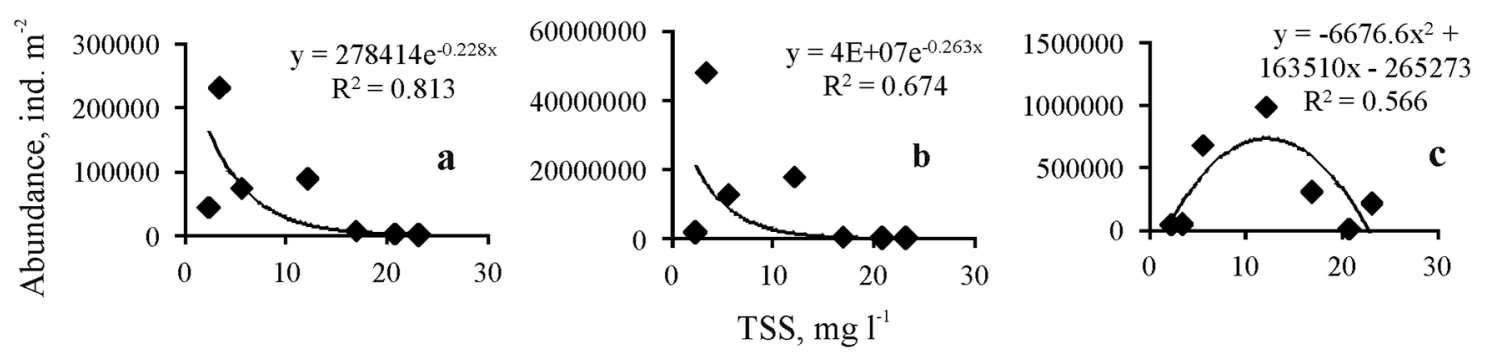

Fig. 2. Relationship between total meiobenthos (a), Harpacticoida (b) and Nematoda (c) abundance with TSS in bottom community (Bay Sivah, 2018, May).

\section{Results}

Between the 14th and 17th May 2018 measurements, which were made at 13 points, showed that salinity fluctuated from 30 to $82 \mathrm{~g} \mathrm{l}^{-1}$, temperature from 19.5 to $26^{\circ} \mathrm{C}$, TSS from 2.37 to $24.76 \mathrm{mg} \mathrm{l}^{-1}$ and DOM from 2.66 to $4.16 \mathrm{mg} \mathrm{l}^{-1}$ (Tab. 1). Minimum of salinity, TSS and DOM were found in the northernmost site, and maximum values of these parameters in the southernmost point. Values of TSS $(R=0.928, p=0.001)$ and DOM $(R=0.913, p=0.001)$ significantly correlated with salinity. On the 19th and 20th June 2018, salinity varied from 69 to $88 \mathrm{~g} \mathrm{l}^{-1}$ and temperature from 24 to $28.3^{\circ} \mathrm{C}$ at three points of the May sampling. TSS and DOM were not evaluated.

\subsection{Meiobenthos in bottom community}

Eleven samples were analyzed, with results showing that there were seven meiobenthic macrotaxa on and in soft bottom sediments: Nematoda, Harpacticoida, Ostracoda, Turbellaria, Acarina, Foramanifera, Ciliata. There was no meiobenthos in one sample at the site with a strong smell of hydrogen sulfide when taking this sample. No significant correlation between the number of meiobenthic taxa in a sample and salinity was found (Tab. 1). Harpacticoida (in $100 \%$ of all samples with meiobenthos) and Nematoda (in $80 \%$ ) were the most common taxa. Turbellaria was in $70 \%$ of the samples, Ciliata in $60 \%$, Ostracoda in $40 \%$, and
Foramanifera in $20 \%$. The average abundance of meiobenthos was 264847 ind. $\mathrm{m}^{-2}(\mathrm{CV}=1.23)$ (Tab. 2), and on average, it contributed $82 \%$ in total zoobenthos abundance. There was one exception where macrobenthos accounted for $72 \%$ due to larvae of Chironomidae. In the samples, average Harpacticoida contribution in total zoobenthos was $21 \%$, and Nematoda and Turbellaria equally accounted for $19 \%$. Nematoda contributed $37 \%$ in average meiobenthic abundance on bottom, Turbellaria 31\%, Harpacticoida 22\%, Ciliata $9 \%$, and Ostracoda $<1 \%$. Abundance of total meiobenthos did not demonstrate any correlation with salinity and DOM. Maximum and minimum abundance of total meiobenthos was recorded at a concentration of TSS 12 and $23 \mathrm{mg} \mathrm{l}^{-1}$, respectively. There was some trend of a relationship between an abundance change of total meiobentos and TSS, and a significant non-linear relationship was found (Fig. 2a) $(R=0.902, p=0.005)$.

\subsubsection{Nematoda}

In total, sixteen species of Nematoda were found on the bottom, and five of them were at salinity of only $30 \mathrm{~g}^{-1}$ (Tab. 3). The number of species in a sample fluctuated from 1 to 11 (3.75 on average) (Tab. 1), and this number did not correlate with salinity, TSS and DOM. Thalassomonhystera parva (Bastian, 1865) and Ethmolaimus multipapillatus Paramonov, 1926 were the most common species; they were in $50 \%$ of all samples with Nematoda (Tab. 3). Theristus sp., 
N. Shadrin et al.: Knowl. Manag. Aquat. Ecosyst. 2019, 420, 36

Table 3. The characteristics of the Nematoda taxocene in Bay Sivash (2018, May-June).

\begin{tabular}{|c|c|c|c|c|}
\hline \multirow[t]{2}{*}{ Species } & \multirow[t]{2}{*}{$\mathrm{FO}, \%$} & \multicolumn{2}{|c|}{ Abundance, ind. $\mathrm{m}^{-2}$} & \multirow[t]{2}{*}{ Salinity range, $\mathrm{g} 1^{-1}$} \\
\hline & & Range & Average & \\
\hline
\end{tabular}

Class Chromadorea

Bottom community

\section{Order Monhysterida}

Family Linhomoeidae

Terschellingia longicaudata de Man, 1907

T. cf. antonovi Filipjev, 1922

$\begin{array}{llll}0.125 & 434 & 54 & 76 \\ 0.125 & 2604 & 325.5 & 76 \\ 0.250 & 1736-2105 & 480 & 75-76 \\ & & & \\ 0.375 & 2105-3368 & 1064 & 56-77 \\ 0.250 & 434-1579 & 252 & 75-77 \\ 0.125 & 842 & 151 & 30 \\ & & & \\ 0.50 & 7578-729410 & 109532 & 75-88 \\ 0.125 & 421 & 53 & 30 \\ 0.375 & 652-129130 & 16603 & 75-88\end{array}$

T. cf. pontica Filipjev, 1918

Family Xyalidae

Theristus $\mathrm{sp}$.

Th. littoralis Filipjev, 1922

Daptonema maeoticum (Filipjev, 1922)

Family Monhysteridae

Thalassomonhystera parva (Bastian, 1865)

Th. attenuata (Filipjev, 1922)

0.375

$652-129130$

16603

Order Chromadorida

Family Ethmolaimidae

Ethmolaimus multipapillatus Paramonov, 1926

0.500

$842-7824$

1682

$56-88$

Family Chromadoridae

Neochromadora poecilosomoides (Filipjev, 1918)

0.125

842

105

30

Spilophorella campbelli Allgén, 1928

0.125

421

53

30

Order Rhabditida

Family Rhabditidae

Rhabditis? sp.

0.125

1736

217

75

Class Enoplea

Order Dorylaimida

Family Qudsianematidae

Eudorylaimus sp.

0.125

434

54

75

Order Enoplida

Family Oncholaimidae

Oncholaimus brevicaudatus Filipjev, 1918

$\begin{array}{llll}0.375 & 421-868 & 227 & 30-77 \\ 0.125 & 29470 & 3684 & 30 \\ 1-11 / 3.75 & - & - & - \\ 16\left(11^{*}\right) & - & - & -\end{array}$

Metoncholaimus demani (Zur Strassen, 1894)

A number of species in a bottom sample, range/average

The total number of the species on bottom

Floating green algae mat community

\section{Class Chromadorea}

Order Monhysterida

Family Linhomoeidae

Terschellingia cf. antonovi Filipjev, 1922

Family Xyalidae

Theristus sp.

0.143

0.143

0.143

450

64.4

75

Th. latissimus (Filipjev, 1922)

450

64.4

82

Family Monhysteridae

Thalassomonhystera parva (Bastian, 1865)

1.000

1350

193

82

Eumonhystera filiformis (Bastian, 1865)

0.429

$750-531300$

126000

$30-82$

Order Chromadorida

$450-14850$

2445

$56-82$

Family Ethmolaimidae

Ethmolaimus multipapillatus Paramonov, 1926

0.429

$50-4050$

885

$56-82$

Family Chromadoridae

Chromadora nudicapitata Bastian, 1865

0.143

3450

495

30

Cyatholaimus gracilis (Eberth, 1863) Bastian, 1865

0.290

$3600-10350$

1995

$30-52$ 
Table 3. (continued).

\begin{tabular}{|c|c|c|c|c|}
\hline \multirow[t]{2}{*}{ Species } & \multirow[t]{2}{*}{$\mathrm{FO}, \%$} & \multicolumn{2}{|c|}{ Abundance, ind. $\mathrm{m}^{-2}$} & \multirow[t]{2}{*}{ Salinity range, $\mathrm{g}^{-1}$} \\
\hline & & Range & $\overline{\text { Average }}$ & \\
\hline \multicolumn{5}{|l|}{ Class Enoplea } \\
\hline \multicolumn{5}{|l|}{ Order Enoplida } \\
\hline \multicolumn{5}{|l|}{ Family Oncholaimidae } \\
\hline Oncholaimus brevicaudatus Filipjev, 1918 & 0.143 & 1800 & 257 & 75 \\
\hline Metoncholaimus demani (Zur Strassen, 1894) & 0.143 & 1800 & 257 & 52 \\
\hline A number of species in a mat sample, range/average & $1-6 / 3$ & - & - & - \\
\hline The total number of the species in the mats & $10(9 *)$ & - & - & - \\
\hline The total number of the species in the bay & $19\left(13^{*}\right)$ & - & - & - \\
\hline
\end{tabular}

FO - frequency of occurrence; ${ }^{*}-$ the number of species without found only at salinity of $30 \mathrm{~g}^{-1}$.

Eumonhystera filiformis (Bastian, 1865) and Oncholaimus brevicaudatus Filipjev, 1918 were found in 38\% of all samples with Nematoda, and Terschellingia cf. pontica Filipjev, 1918 and Theristus littoralis Filipjev, 1922 in 25\% samples. All other species were found only in single samples. Total abundance of Nematoda fluctuated between 2106 and 862,030 ind. $\mathrm{m}^{-2}$ (97,825 ind. $\mathrm{m}^{-2}$ on average) (Tab. 2). T. parva was also a most abundant species and dominated in $37.5 \%$ of all samples (Tabs. 3 and 4). In other samples, Theristus sp., Metoncholaimus demani (Zur Strassen, 1894) Filipjev, 1918, T. cf. pontica and Th. littoralis dominated (Tab. 4). No significant correlation between abundance of total Nematoda or some species and salinity or DOM was found. There is a significant negative correlation between total abundance of Nematoda and TSS $(R=0.821, p=0.005)$ (Fig. 2b).

\subsubsection{Harpacticoida}

In total, four species of Harpacticoida were found on the bottom: Canuella perplexa Scott T. \& A., 1893, Nitokra spinipes spinipes Boeck, 1865, Cletocamptus retrogressus Schmankevitsch, 1875 and Mesochra rostrata Gurney, 1927 (Tab. 5). One to three species were found in a sample (1.7 on average) (Tab. 1). Total abundance of Harpacticoida (adults and nauplii) varied from 1263 to 101,882 ind. $\mathrm{m}^{-2}$ (57719 ind. $\mathrm{m}^{-2}$ on average) (Tabs. 1 and 5). Nauplii contributed $21 \%$ in total abundance of all Harpacticoida. In adult stages, $M$. rostrata was a most common and abundant species dominating in all samples (Tab. 6). No significant correlation between abundance of total Harpacticoida or some species and salinity and DOM was found. There was some relationship between Harpacticoida abundance and TSS (Fig. 2c), a significant non-linear bell-shaped relationship was found $(R=0.752, p=0.005)$ with a maximum harpacticoid number at a concentration of TSS $=12 \mathrm{mg} \mathrm{l}^{-1}$.

\subsubsection{Ostracoda}

Cyprideis torosa (Jones, 1850) was the single ostracod species in the bottom community.

\subsection{Meiobenthos in the floating mats of filamentous green algae}

Floating mats of filamentous green algae Cladophora sp. were not seen at all points where observations were made.
Macro- and meiobenthos were found in all seven analyzed samples. In the meiobenthos, there were Nematoda, Harpacticoida, Ostracoda, Turbellaria, and Ciliata. Total abundance of the meiobenthos was 327107 ind. $\mathrm{m}^{-2}$ on average $(\mathrm{CV}=1.29)$. Only Nematoda and Harpacticoida, being in all samples, contributed $41 \%$ and $46 \%$ to the total abundance of meiobenthos, respectively. Turbellaria was in $57 \%$ of samples, Ostracoda in $28 \%$ and Ciliata - in $14 \%$ averagely contributing about $1 \%, 0.9 \%$ and $0.5 \%$ to total abundance of meiobenthos, consistently. Significant dependence of the number of meiobenthic macrotaxa, the number of meiobenthos on salinity or DOM was not seen. A significant negative dependence of meiobenthic abundance on TSS $(R=-0.899$, $p=0.001$ ) was observed (Fig. 3a). The part of meiobenthos in total zoobenthos abundance demonstrated a significant exponential decrease with TSS increasing $(R=-0.908$, $p=0.005$ ). Such dependences were not observed in soft bottom meiobenthos. This decrease may be explained by an increase of chironomid larvae abundance.

\subsubsection{Nematoda}

In total, ten species of Nematoda were found in mats, and one of them was only at salinity of $30 \mathrm{~g}^{-1}$ (Tab. 3). In single samples, there were from one to six species ( 3 on average). Only Th. parva was in all samples; E. multipapillatus and E. filiformis were in $43 \%$ of all samples, Cyatholaimus gracilis (Eberth, 1863) Bastian, 1865 were in $29 \%$ of all samples, and all other species were in $12.5 \%$ of all samples. Total abundance of Nematoda varied from 750 to 538500 ind. $\mathrm{m}^{-2}$ (134555 ind. $\mathrm{m}^{-2}$ on average) (Tab. 2). At salinity of $30 \mathrm{~g} \mathrm{l}^{-1}$, C. gracilis dominated, and Th. parva was dominant among adults in all other cases. Salinity did not significantly influence abundance of Nematoda, but TSS significantly influenced abundance (Fig. 3b) $(R=-0.821, p=0.005)$.

\subsubsection{Harpacticoida}

In total, five species of Harpacticoida were found on the bottom: Harpacticus littoralis Sars G.O., 1910, Laophonte setosa Boeck, 1865, N. spinipes spinipes, C. retrogressus and $M$. rostrata (Tab. 5). One to two species were found in a sample (1.4 on average). There were practically no nauplii. Total abundance of Harpacticoida varied from 1500 to 861787 ind. $\mathrm{m}^{-2}$ (149885 ind. $\mathrm{m}^{-2}$ on average) (Tab. 2). $M$. rostrata was a most abundant species dominating in $71 \%$ of all 
N. Shadrin et al.: Knowl. Manag. Aquat. Ecosyst. 2019, 420, 36

Table 4. Long-term changes in taxocene structure of Nematoda on soft bottom sediments of Bay Sivash (2013-2018).

\begin{tabular}{|c|c|c|c|c|c|c|c|c|}
\hline \multirow[t]{2}{*}{ Species } & \multicolumn{3}{|c|}{$2013^{*}$} & \multicolumn{3}{|c|}{$2015^{*}$} & \multicolumn{2}{|r|}{2018} \\
\hline & FO, \% & $\mathrm{D}, \%$ & $\mathrm{SD}, \%$ & FO, \% & $\mathrm{D}, \%$ & $\mathrm{SD}, \%$ & FO, \% & $\mathrm{D}, \% \quad \mathrm{SD}, \%$ \\
\hline
\end{tabular}

\section{Class Chromadorea}

Order Araeolaimida

Family Axonolaimidae

Ascolaimus elegans (Hendelberg \& Jensen, 1993)

Family Diplopeltidae

Araeolaimus ponticus (Filipjev, 1922)

Family Comesomatidae

Sabatieria pulchra (Schneider, 1906)

Order Chromadorida

Chromadorida gen. sp.

Family Chromadoridae

Chromadora nudicapitata (Bastian, 1865)

Chromadorita cf. leuckarti (de Man,1876) (Filipjev, 1929)

Spilophorella campbelli (Allgén, 1928)

Neochromadora poecilosomoides (Filipjev, 1918)

Family Ethmolaimidae

Ethmolaimus multipapillatus (Paramonov, 1926)

Order Rhabditida

Family Rhabditidae

Rhabditis? sp.

\section{Order Desmodorida}

Family Desmodoridae

Chromaspirina sp.

Cyatholaimus gracilis (Eberth, 1863) (Bastian, 1865)

Molgolaimus sp.

$\begin{array}{lllllllll}12.5 & 0 & 0 & 50 & 0 & 25 & - & - & - \\ 12.5 & - & - & 25 & - & - & - & - & - \\ 50 & 0 & 0 & 100 & 12.5 & 0 & - & - & - \\ 12.5 & - & - & - & - & - & - & - & - \\ 25 & 0 & 12.5 & - & - & - & - & - & - \\ 12.5 & 0 & 0 & - & - & - & - & - & - \\ - & - & - & 75 & 0 & 0 & 12.5^{* *} & 0 & 0 \\ 12.5 & 0 & 12.5 & - & - & - & 12.5^{* *} & 0 & 12.5 \\ 12.5 & 0 & 12.5 & - & - & - & 50 & 0 & 12.5\end{array}$

Order Monhysterida

Family Linhomoeidae

Linhomoeidae gen. sp.

Terschellingia longicaudatade (Man, 1907)

T. cf. antonovi (Filipjev, 1922)

T. cf. pontica (Filipjev, 1918)

Family Xyalidae

Cobbia sp.

Daptonema maeoticum (Filipjev, 1922)

D. setosus (Bütschli, 1874)

D. longicaudatum (Filipjev 1922) (Lorenzen, 1977)

Theristus sp.

Th. cf. latissimus (Filipjev, 1922)

Th. littoralis Filipjev, 1922

Th. sabulicola (Filipjev, 1918) (Wieser, 1956)

Family Monhysteridae

Monhystera sp.

Eumonhystera filiformis (Bastian, 1865)

Gammarine maampullocauda (Paramonov, 1926)

Thalassomonhystera attenuate (Filipjev, 1922)

Th. parva (Bastian, 1865)

Family Sphaerolaimidae

Sphaerolaimus sp.

Sph. gracilis (deMan, 1876)

Sph. macrocirculus (Filipjev, 1918)

Sph. ostreae (Filipjev, 1918)

\section{Class Enoplea}

\section{OrderEnoplida}

Family Tripyloididae

Bathylaimus australis (Cobb, 1894)

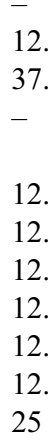$$
12.5
$$

50

$-$

$0 \quad 0$

$\begin{array}{rr}2.5 & - \\ 37.5 & 0 \\ - & 0\end{array}$

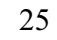

75

100

25

12.5

12.5

25

0

0

12.50

$\begin{array}{lllllllll}12.5 & 0 & 0 & - & - & - & - & - & - \\ 12.5 & - & - & - & - & - & 12.5^{* *} & 0 & 12.5 \\ 12.5 & - & - & - & - & - & - & - & - \\ 12.5 & - & - & - & - & - & - & - & - \\ 12.5 & 0 & 12.5 & 25 & 0 & 0 & 37.5 & 0 & 12.5 \\ 12.5 & 12.5 & 0 & - & - & - & - & - & - \\ 25 & 12.5 & 12.5 & - & - & - & 25 & 12.5 & 0 \\ 12.5 & 0 & 0 & - & - & - & - & - & - \\ & & & & & & & & \\ 37.5 & 12.5 & 0 & 50 & 0 & 0 & - & - & - \\ 12.5 & 0 & 0 & - & - & - & 37.5 & 0 & 12.5 \\ 12.5 & 0 & 0 & - & - & - & - & - & - \\ - & - & - & - & - & - & 12.5^{* *} & 0 & 0 \\ - & - & - & - & - & - & 37.5 & 37.5 & 0 \\ 12.5 & 0 & 0 & - & - & - & - & - & - \\ - & - & - & 25 & 0 & 25 & - & - & - \\ - & - & - & 50 & 0 & 0 & - & - & - \\ - & - & - & 25 & 0 & 25 & - & - & -\end{array}$

$\begin{array}{lllllllll}12.5 & 0 & 0 & - & - & - & - & - & - \\ 12.5 & - & - & - & - & - & 12.5^{* *} & 0 & 12.5 \\ 12.5 & - & - & - & - & - & - & - & - \\ 12.5 & - & - & - & - & - & - & - & - \\ 12.5 & 0 & 12.5 & 25 & 0 & 0 & 37.5 & 0 & 12.5 \\ 12.5 & 12.5 & 0 & - & - & - & - & - & - \\ 25 & 12.5 & 12.5 & - & - & - & 25 & 12.5 & 0 \\ 12.5 & 0 & 0 & - & - & - & - & - & - \\ & & & & & & & & \\ 37.5 & 12.5 & 0 & 50 & 0 & 0 & - & - & - \\ 12.5 & 0 & 0 & - & - & - & 37.5 & 0 & 12.5 \\ 12.5 & 0 & 0 & - & - & - & - & - & - \\ - & - & - & - & - & - & 12.5 * * & 0 & 0 \\ - & - & - & - & - & - & 37.5 & 37.5 & 0 \\ 12.5 & 0 & 0 & - & - & - & - & - & - \\ - & - & - & 25 & 0 & 25 & - & - & - \\ - & - & - & 50 & 0 & 0 & - & - & - \\ - & - & - & 25 & 0 & 25 & - & - & -\end{array}$


Table 4. (continued).

\begin{tabular}{|c|c|c|c|c|c|c|c|c|c|}
\hline \multirow[t]{2}{*}{ Species } & \multicolumn{3}{|c|}{$2013 *$} & \multicolumn{3}{|c|}{$2015^{*}$} & \multicolumn{3}{|c|}{2018} \\
\hline & $\mathrm{FO}, \%$ & $\mathrm{D}, \%$ & $\mathrm{SD}, \%$ & $\mathrm{FO}, \%$ & $\mathrm{D}, \%$ & $\mathrm{SD}, \%$ & $\mathrm{FO}, \%$ & $\mathrm{D}, \%$ & $\mathrm{SD}, \%$ \\
\hline \multicolumn{10}{|l|}{ Family Oncholaimidae } \\
\hline Viscosia $\mathrm{sp}$. & - & - & - & 100 & 0 & 25 & - & - & - \\
\hline V. cf. cobbi (Filipjev, 1918) & 12.5 & 0 & 12.5 & 25 & 0 & 0 & - & - & - \\
\hline V. glabra (Bastian, 1865) (de Man, 1890) & 12.5 & 0 & 0 & - & - & - & - & - & - \\
\hline V. minor (Filipjev, 1918) & - & - & - & 25 & 0 & 0 & - & - & - \\
\hline \multicolumn{10}{|l|}{ Family Enchelidiidae } \\
\hline $\begin{array}{l}\text { Catalaimus sp. } \\
\text { Family Enoplidae }\end{array}$ & - & - & - & 25 & 0 & 0 & - & - & - \\
\hline \multicolumn{10}{|l|}{ Family Oncholaimidae } \\
\hline Oncholaimellus mediterraneus (Sch.-Stekh, 1942) & - & - & - & 75 & 0 & 25 & - & - & - \\
\hline Oncholaimus brevicaudatus (Filipjev, 1918) & 25 & 0 & 0 & - & - & - & 37.5 & 0 & 12.5 \\
\hline O. campylocercoides (De Coninck \& Sch.-Stekh. 1933) & - & - & - & 50 & 0 & 0 & - & - & - \\
\hline \multicolumn{10}{|l|}{ Family Thoracostomopsidae } \\
\hline Mesacanthion conicum (Filipjev 1918) & 12.5 & - & - & - & - & - & - & - & - \\
\hline $\begin{array}{l}\text { Order Dorylaimida } \\
\text { Family Qudsianematidae }\end{array}$ & & & & & & & & & \\
\hline Eudorylaimus sp. & - & - & - & - & - & - & 12.5 & 0 & 0 \\
\hline Total number of species and forms & & 30 & & & 22 & & & $6(11 * *$ & \\
\hline Average number of species in a sample & & 5 & & & 10 & & & 4 & \\
\hline Average salinity (range), $\mathrm{g}^{-1}$ & & $22(10-4$ & & & $52(28-75$ & & & $9(30-8$ & \\
\hline
\end{tabular}

FO - frequency of occurrence; D - species was dominant; SD - species was subdominant; * - data from Sergeeva et al. (2019); ** - species found only at salinity of $30 \mathrm{~g}^{-1} ; * * *-$ the number of the species without samples taken at salinity of $30 \mathrm{~g}^{-1}$.

samples and $N$. spinipes spinipes were in $14 \%$. At salinity of $30 \mathrm{gl}^{-1}$, H. littoralis dominated, and L. setosa was subdominant. Salinity significantly influenced abundance of Harpacticoida $(R=-0.806, p=0.005)$, as well as TSS $(R=-0.965, p=0.001)$ (Fig. 3c, d).

There was no correlation between abundance of Harpacticoida and Nematoda. In the samples, the proportion between abundance of Harpacticoida and Nematoda $(\mathrm{N} / \mathrm{H})$ varied over a wide range. Salinity, DOM and TSS did not have a significant influence on $\mathrm{N} / \mathrm{H}$ proportion, and the authors cannot suggest any explanation of a cause, which may be responsible for this variability of the proportion.

\subsubsection{Ostracoda}

Two species of Ostracoda - Cytherois cepa Klie, 1937 and Loxoconcha sp. (L. bulgarica Caraion, 1960?) were found in the floating mats.

\subsection{Mats vs soft bottom}

The number of macrotaxa in the meiobenthos (seven) was higher in the bottom community than in the mats (five). Average total abundance of the meiobenthos in the mats was higher than on the bottom (Tab. 2). No significant correlation between the abundance of benthic animals at the bottom and in the mats at the same points was observed.

Structure of the meiobenthos was different on the bottom and in the mats. If the average abundance of Nematoda was higher than that of Harpacticoida in the bottom community, there was the opposite situation in the mats (Tab. 2). Species richness of Nematoda was higher at 1.6 times in the bottom community (Tab. 3). Species composition of Nematoda and Ostracoda (Tabs. 3 and 5) was significantly different in the mats and the bottom community according to the calculated indexes of Jaccard (37\% for Nematoda and $0 \%$ for Ostracoda) and Chekanovski-Sørensen-Dice (54\% for Nematoda); the threshold values to make a conclusion about the similarity are $42 \%$ and $59 \%$, respectively. Species richness of Harpacticoida was very close (four and five) in both communities (Tab. 3). Species composition of Harpacticoida was same in the mats and bottom community; calculated indexes of Jaccard (50\%) and Chekanovski-Sørensen-Dice (67\%) were higher than their threshold values. Additionally, to the harpacticoid species, which were found in the mats and on the bottom, three more species were found in the plankton samples only: Ameira parvula (Claus, 1866), Harpacticus flexus Brady et Robertson D., 1873 and Metis ignea ignea Philippi, 1843. The meiobenthos on the bottom and in mats demonstrated the different responses on the spatial gradients of salinity and TSS in Sivash.

\section{Discussion}

When the channel was closed, salinity gradually increased in Bay Sivash: the average salinity was $25 \mathrm{~g} \mathrm{l}^{-1}$ in 2013 (Shadrin et al., 2018), the average salinity reached $52.0 \mathrm{~g} \mathrm{l}^{-1}$ in 
N. Shadrin et al.: Knowl. Manag. Aquat. Ecosyst. 2019, 420, 36

Table 5. The characteristics of the Harpacticoida and Ostracoda taxocenes in Bay Sivash (2018, May-June).

\begin{tabular}{llll}
\hline Species & FO, $\%$ & $\begin{array}{l}\text { Abundance, ind. } \mathrm{m}^{-2} \\
\end{array}$ & Range \\
\hline
\end{tabular}

Class Hexanauplia

In bottom community

Order Canuelloida

Family Canuellidae

Canuella perplexa (Scott T. \& A., 1893)

\section{Order Harpacticoida}

Family Ameiridae

Nitokra spinipes spinipes (Boeck, 1865)

Family Canthocamptidae

Cletocamptus retrogressus (Schmankevitsch, 1875)

Mesochra rostrata (Gurney, 1927)

The number of species in a bottom sample, range/average

The total number of species in bottom community

Class Ostracoda

\section{Order Podocopida}

Family Cytherideidae

Cyprideis torosa (Jones, 1850)

The total number of species in bottom community

\section{Class Hexanauplia}

\section{Order Harpacticoida}

Family Ameiridae

Nitokra spinipes spinipes (Boeck, 1865)

Family Canthocamptidae

Mesochra rostrata (Gurney, 1927)

Cletocamptus retrogressus (Schmankevitsch, 1875)

Family Harpacticidae

Harpacticus littoralis (Sars G.O., 1910)

Family Laophontidae

Laophonte setosa (Boeck, 1865)

The number of species in a mat sample, range / average

The total number of species in mats

The total number of species in bottom and mat communities

Class Ostracoda

\section{Order Podocopida}

Family Paradoxostomatidae

Cytherois cepa (Klie, 1937)

Family Loxoconchidae

Loxoconcha sp. (L. bulgarica Caraion, 1960)

The total number of species in mats

The total number of species in bottom and mat communities
10

842

842

50
10
70
$1-2 / 1.9$
4

40
1
In floating mats

$\begin{array}{lll}421-17261 & 3538 & 30-88 \\ 842 & 84 & 56 \\ 842-101882 & 16051 & 30-88 \\ - & - & - \\ - & - & - \\ & & \\ & & \\ 421-7999 & 1362 & 30-88 \\ - & - & -\end{array}$

\begin{tabular}{|c|c|c|c|}
\hline 0.143 & 10 & 1.4 & 77 \\
\hline 0.571 & $10-460$ & 77 & $52-77$ \\
\hline 0.143 & 10 & 1.4 & 56 \\
\hline 0.143 & 460 & 66 & 30 \\
\hline 0.143 & 230 & 32.9 & 30 \\
\hline $1-2 / 1.4$ & - & - & - \\
\hline 5 & - & - & - \\
\hline 6 & - & - & - \\
\hline 14 & 1250 & 179 & 30 \\
\hline 14 & 1250 & 179 & 30 \\
\hline 2 & - & - & - \\
\hline 3 & - & - & - \\
\hline
\end{tabular}

FO - frequency of occurrence.

2015 (Shadrin et al., 2018), $69.5 \mathrm{~g} \mathrm{l}^{-1}$ in 2017 (Soloveva et al., 2019), and $69.0 \mathrm{~g} \mathrm{l}^{-1}$ in 2018 (this study). In these years, the average concentration of TSS also increased: it was $3.6 \mathrm{mg}^{-1}$ in 2013 (Shadrin et al., 2018), 10.1 to $10.5 \mathrm{mg} \mathrm{l}^{-1}$ in 2014 and 2015 (Shadrin et al., 2018), and $21.8 \mathrm{mg}^{-1}$ in 2018. Interannual variability in salinity and TSS significantly correlate with each other $(p=0.05)$, as well as in the spatial changes in 2018. A TSS increase with a salinity growth was also recorded in the Crimean saline shallow lakes (Boulion et al., 1989) as well as in saline waters of other regions (LópezGonzález et al., 1997; Schallenberg and Burns, 2003; Abdo,
2005; Elloumi et al., 2006; Velasco et al., 2006; Telesh and Khlebovich, 2010). The DOM average concentration did not demonstrate a gradual increase, it fluctuated: $2.9 \mathrm{mg}^{-1}$ (2013); $1.1 \mathrm{mg} \mathrm{l}^{-1}$ (2014, October), $2.0 \mathrm{mg} \mathrm{l}^{-1}$ (2015), and $3.5 \mathrm{mg} \mathrm{l}^{-1}$ (2018). It has been shown previously that oxygen content decreased and temperature slightly increased in the lagoon due to a salinity increase (Shadrin et al., 2018; Soloveva et al., 2019). These changes also indirectly influence distribution and dynamics of the meiobenthos. Obviously, there is multicausality in transformation of the meiobenthos in the bay. Therefore, it is a very difficult task to identify and 
N. Shadrin et al.: Knowl. Manag. Aquat. Ecosyst. 2019, 420, 36

Table 6. Long-term changes of a species structure in the Harpacticoida and Ostracoda taxocenes of Bay Sivash during 2013-2018.

\begin{tabular}{|c|c|c|c|c|c|c|c|c|c|}
\hline \multirow[t]{2}{*}{ Species } & \multicolumn{3}{|c|}{$2013^{1}$} & \multicolumn{3}{|c|}{$2015^{1}$} & \multicolumn{3}{|c|}{2018} \\
\hline & $\mathrm{FO}, \%$ & $\mathrm{D}, \%$ & $\mathrm{SD}, \%$ & FO, $\%$ & $\mathrm{D}, \%$ & $\mathrm{SD}, \%$ & $\mathrm{FO}, \%$ & $\mathrm{D}, \%$ & $\mathrm{SD}, \%$ \\
\hline
\end{tabular}

\section{Class Hexanauplia \\ Order Canuelloida}

Family Canuellidae

Canuella perplexa (Scott T. et A., 1893)

Order Harpacticoida

Family Ameiridae

Ameira parvula (Claus, 1866) 50

Cletocamptus retrogressus (Schmankevitsch, 1875)

Nitokra spinipes spinipes (Boeck, 1865)

Family Canthocamptidae

Mesochra heldti (Monard, 1935)

Mesochra rostrata (Gurney, 1927)

Family Harpacticidae

Harpacticus littoralis (Sars G.O., 1910)

Harpacticus flexus (Brady et Robertson D., 1873)

Family Laophontidae

Laophonte setosa (Boeck, 1865)

Family Metidae

Metis ignea ignea (Philippi, 1843)

Family Tachidiidae

Microarthridion littorale (Poppe, 1881)

Number of species

Class Ostracoda

\section{Order Podocopida}

Family Cytherideidae

Cyprideis torosa (Jones, 1850)

Family Leptocytheridae

Leptocythere devexa (Schornikov, 1966)

Family Loxoconchidae

Loxoconcha bulgarica (Caraion, 1960)

Loxoconcha aestuarii (Marinov, 1963)

Family Paradoxostomatidae

Cytherois cepa (Klie, 1937)

Number of species

Average salinity (range), $\mathrm{g}^{-1}$

$\begin{array}{lll}100 & 0 & 75 \\ & & \\ 50 & 0 & 50 \\ 0 & 0 & 0 \\ 25 & 0 & 0 \\ 50 & 0 & 50 \\ 100 & 100 & 0 \\ 0 & 0 & 0 \\ 50 & 0 & 25 \\ 0 & 0 & 0 \\ 0 & 0 & 0 \\ 0 & 0 & 0\end{array}$

60

\begin{tabular}{lllll}
0 & 30 & 10 & 10 & 0 \\
& & & & \\
0 & 0 & $+* *$ & - & - \\
10 & 10 & 20 & 10 & 10 \\
0 & 0 & 10 & 0 & 10 \\
0 & 0 & 20 & 0 & 20 \\
40 & 30 & 70 & 50 & 20 \\
0 & 0 & 10 & 10 & 0 \\
0 & 0 & $+* *$ & - & - \\
0 & 0 & $10 * *$ & 0 & 10 \\
0 & 10 & $+*$ & - & - \\
10 & 10 & 0 & 0 & 0 \\
6 & & \multicolumn{3}{c}{$9\left(6^{* * * *}\right)$}
\end{tabular}

FO - frequency of occurrence; D - species was dominant; SD - species was subdominant; ${ }^{1}$ - data from Kolesnikova et al., 2017 and Drapun et al., 2017; ${ }^{2}$-data for $2004 ; * *$ - found only in the plankton samples at salinity of $30 \mathrm{~g} \mathrm{l}^{-1} ;{ }^{*}$ - found only in the plankton samples at salinity of $52 \mathrm{~g} \mathrm{l}^{-1} ; * * *$ - found only at salinity of $30 \mathrm{~g}^{-1} ; * * * *-$ without species found only at salinity $30 \mathrm{~g}^{-1}$.

quantify the effects caused by the different factors which contributed to a whole response of the meiobenthos. When discussing a relationship between a salinity increase and transformation of the meiobenthos, we need to keep the following factors in mind.

The number of meiobenthic macrotaxa did not significantly change in the bottom community; it fluctuated between 6 and 8 (Tab. 2). In the Aral Sea, among meiobenthic animal groups, there were Nematoda, Harpacticoida, Ostracoda, Turbellaria, Ciliata, and Foraminifera also recorded at salinity of 88 to $100 \mathrm{~g}^{-1}$ (Mokievsky and Miljutina, 2011). The structure of the meiobenthos in the bottom community changed from 2013, the shares of Nematoda and Harpacticoida in total abundance gradually decreased (Tab. 2) but Turbellaria increased from $2 \%$ (on average) in 2013 to $13 \%$ in 2015 and to
$31 \%$ in 2018 ; to made these calculations, the authors used their own primary data (Shadrin et al., 2018). Total abundance of the meiobenthos sharply increased between 2013 and 2015 (Shadrin et al., 2018) but, in 2017 (Soloveva et al., 2019) and 2018, total abundance was only slightly higher than in 2013. Shares of Harpacticoida and Nematoda in total abundance of the meiobenthos on the bottom gradually decreased from 2013 to 2018 due mainly to an increase in the proportion of Turbellaria. Contrary to other years, Ostracoda dominated $(60-98 \%$ of total meiobenthic abundance) in all the bottom samples in 2017 (Soloveva et al., 2019). In 2015, the average contribution of Ostracoda to the total abundance of the bottom meiobenthos was $17 \%$ varying from $<1$ to $56 \%$ in the samples (Shadrin et al., 2018). In 2015 , ostracods were also abundant in plankton, dominating 

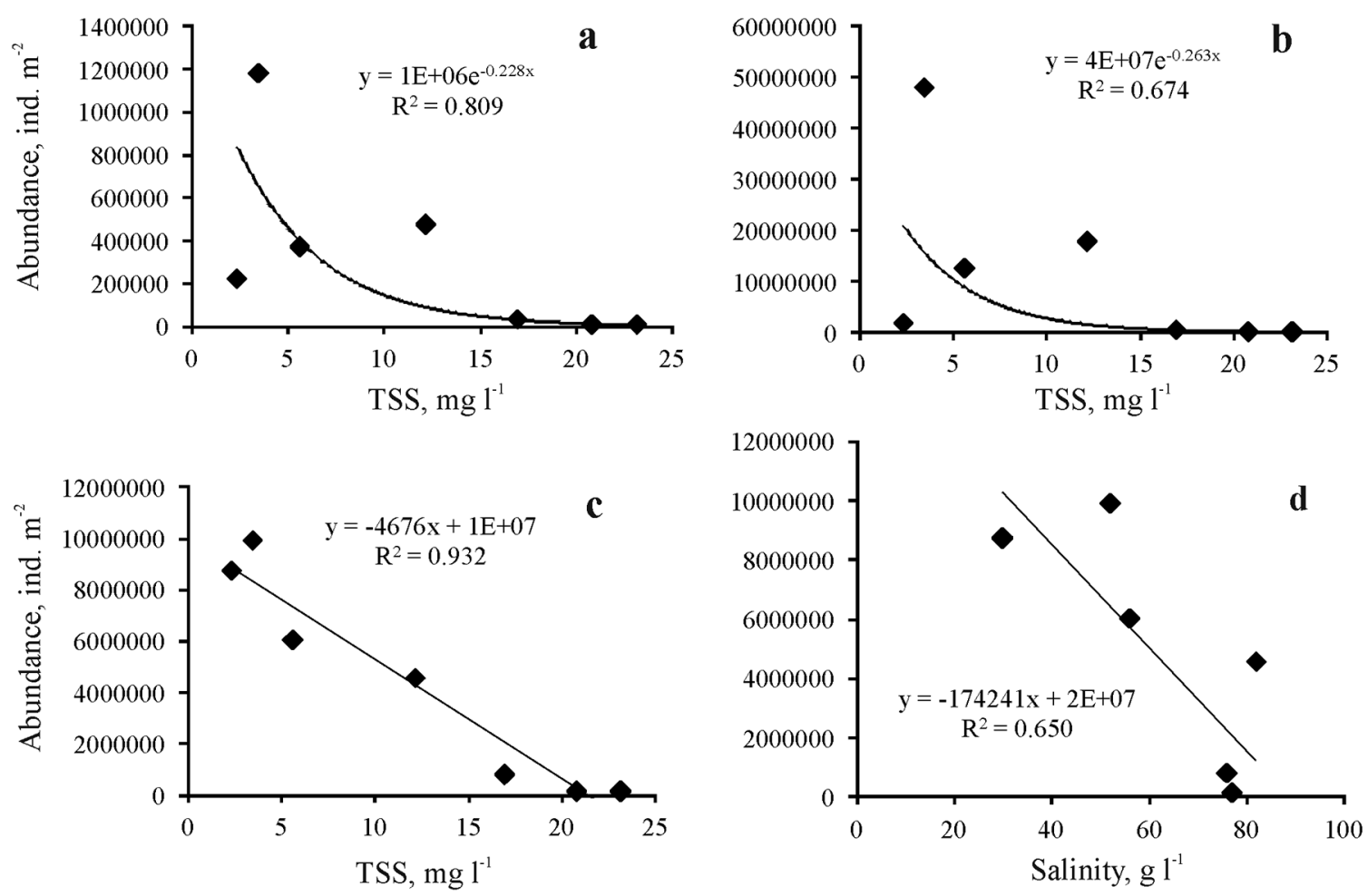

Fig. 3. Relationship between total meiobenthos (a), Nematoda (b) and Harpacticoida (c) abundance with TSS and relationship between Harpacticoida abundance and salinity (d) in algal mats (Bay Sivash, 2018, May).

in some samples (Drapun et al., 2017). Similar trends in the changes of the bottom meiobenthos were observed in the Aral Sea during a long-term salinity increase from brackish water up to 88-109 $\mathrm{g}^{-1}$ (Mokievsky, 2009). The authors conclude that quantitative characteristics of the meiobenthos as a whole are quite stable in a salinity range from 22 to $30 \mathrm{~g}^{-1}$ up to 80 to $100 \mathrm{~g} \mathrm{l}^{-1}$. After Mokievsky, the authors also think that a salinity factor is less influential in directly determining total abundance of the meiobenthos on the bottom than some other factors such as oxygen concentration, food resources, different sediment characteristics and TSS. During our study, TSS was a more influential factor than salinity (Fig. 3). In addition to mention above, salinity has also other indirect impacts on abundance of the meiobenthos through its food resources. Primary production of the bottom microalgae was found may rise as salinity increased, and a shift from planktonic to benthic microalgae dominance was observed in some cases (Segal et al., 2006; Shadrin and Anufriieva, 2018). High TSS and its sedimentation rate suppress distribution and abundance of the phytobenthos and the meiobenthos more than salinity changes (Gambi et al., 2003) due to depressing primary production as well as feeding and reproduction of animals (Gambi et al., 2003; Shadrin and Litvinchuk, 2005; Farkas et al., 2017).

Floating mats of filamentous green algae $C$. siwaschensis became an important component of the Sivash ecosystem from 2015 and occupy large areas reaching high biomass of up to 2 to $3 \mathrm{~kg} \mathrm{~m}^{-2}$ (wet mass) (Drapun et al., 2017; Shadrin et al., 2018). Such floating mats also played a very important role in hypersaline Bay Sivash before construction of the NorthCrimea Canal (Vorobyev, 1940). It is a unique large biotope for the meiobenthos, where the meiobenthos has specific features and may reach higher abundance than on the bottom (Tab. 2). However, the mats are not only home for large numbers of meiobenthic animals. A lot of epibiontic microalgae dwell on filaments of Cladophora sp. (Zulkifly et al., 2012) providing food for meiobenthic animals. Hypoxic and anoxic events may form in the hypersaline lagoons, including in Sivash, usually under floating mats (Shadrin and Anufriieva, 2013; Shadrin et al., 2018). In such cases, the floating mats play a vital role of a refuge for the survival of meiobenthic animals which migrate from the bottom up to the floating mats and/or plankton. Active emergence of Harpacticoida from sediments is higher than of Nematoda during a hypoxic environment and increased salinity (Armonies, 1988), and this may explain the increased share of harpacticoids in the mats compared with the bottom.

Before this study, 25 species of Nematoda inhabiting Crimean hypersaline waters were known (Sergeeva et al., 2019); two more species Th. parva and E. multipapillatus were found in 2018, which are the most common and abundant species in the bay now. In Crimean hypersaline waters, 9 species of Harpacticoida were found previously (Anufriieva, 2015; Kolesnikova et al., 2017); four of them were recorded in this study. Between 2013 and 2018, a change of the Nematoda species number significantly negatively correlated with a salinity variability (Tab. 6), and relation can be approximated $(R=-0.994, p=0.02)$ :

$$
Y_{1}=37.8-0.32 S
$$

where $Y_{1}$ - the number of observed species; $S$ - salinity, $\mathrm{g}^{-1}$. 
In total, 19 species of Nematoda were found in 2018, and among them, 16 species on the bottom and 10 in floating algal mats; 7 species $(37 \%)$ were in both habitats. Evidently, not all species of Nematoda living in Bay Sivash have been recorded in this study, so the question is to what degree the fauna of Nematoda in the bay has been explored? There is a significant tight correlation between the number of samples analyzed and the number of observed species for different taxa of animals (Pesenko, 1982; Shen et al., 2003, Anufriieva et al., 2014; El-Shabrawy et al., 2018). Different types of functions were used to describe the relationship between the number of identified specimens/the number of samples and the found species richness; the power and logarithmic functions are the most often used. Relying upon their own new data, the authors found that the species accumulation curve for Nematoda on the bottom is best described by the following logarithmic function $(R=0.961, p=0.001)$ :

$$
Y_{1}=6.57 \ln \left(X_{1}\right)+0.91
$$

where $Y_{1}$ - the number of observed species in bottom community; $\ln \left(X_{1}\right)$ - logarithm of the number of analyzed bottom samples.

The species accumulation curve for Nematoda in floating mats is best described by $(R=0.917, \mathrm{p}=0.005)$ :

$$
Y_{2}=2.86 \ln \left(X_{2}\right)+2.8
$$

where $Y_{2}$ is the number of observed species in mat community, $\ln \left(X_{2}\right)$ is the logarithm of the number of analyzed mat samples.

Both equations correspond to one of the many possible orderings of available samples. The authors calculated 10 more accumulation curves using 10 different orderings of the available samples. The calculated species richness for 500 samples, using different orderings of the samples, was estimated as $(36 \pm 7)$ species of nematodes in bottom community, and $(23 \pm 4)$ in the mats. Taking into account that $37 \%$ of all species of Nematoda are common for both communities, the authors concluded that there are approximately 43 species of Nematoda inhabiting in Bay Sivash currently.

Is species richness of Nematoda changing in Bay Sivash after the North Crimean Canal ceased? To look for an answer to this question, the authors used published data obtained in 2013 and 2015 (Sergeeva et al., 2019). In 2013 and 2015, species richness of Nematoda was analyzed only in the bottom community not in mats. The species accumulation curves for 2013 and 2015 were calculated as for 2018 above. Calculated value for 2015 was $(48 \pm 9)$ species of Nematoda in bottom community and $(63 \pm 7)$ for 2013 . There was a significant decrease of species richness of Nematoda from 2013 to 2018, which negatively correlates with salinity.

In the Large Aral Sea, in 2013, twelve species of nematodes were found in the bottom community at salinity about 88 to $100 \mathrm{gl}^{-1}$ (Mokievsky and Miljutina, 2011) which is very close to the number found in Bay Sivash in 2018. In the Aral Sea, the most common dominating species were the same as in Bay Sivash (in 2018): T. parva, E. multipapillatus, and Monhystera sp. (Mokievsky and Miljutina, 2011). There were ten species of Nematoda in the Aral Sea before a salinity increase began (Plotnikov, 2016); none of them was recorded in 2003.

In total, six species of Harpacticoida were found in 2018, and among them, 4 species on the bottom and 5 in floating algal mats; three species $(50 \%)$ were in both habitats. No correlation between the number of species and salinity was found in a long-term change in 2013 to 2018. Evidently, not all species of Harpacticoida living in Bay Sivash have been recorded in this study, so the authors made the same calculation and analysis as for Nematoda above. If 500 samples were to be analyzed, it may be expected to find $(9 \pm 1)$ species of Harpacticoida in the bottom community, and $(11 \pm 1)$ species in the mats. Using own published data (Shadrin et al., 2018), the authors made calculations for 2015 and 2013. In 2015, it may be expected to find $(8 \pm 1)$ species of Harpacticoida in the bottom community and $(19 \pm 30)$ species in 2013. There was a significant $(p=0.001)$ decrease in species richness of Harpacticoida between 2013 and 2015; no changes occurred between 2015 and 2018 unlike as observed in Nematoda. Before salinization of the Aral Sea, there were 16 species of Harpacticoida in it (Plotnikov, 2016). In 2003, only a single species of Harpacticoida - C. retrogressus was found at salinity of 88 to $100 \mathrm{~g}^{-1}$ (Mokievsky and Miljutina, 2011), which is a common and halotolerant species in Crimean hypersaline waters found also in Bay Sivash.

There are differences between Nematoda and Harpacticoida not only in responses of species richness to the salinity change but in changes of species composition also (Tabs. 2, 4, $6,7)$. In species composition of Harpacticoida, significant changes occurred between 2013 and 2015, but no significant differences between 2013 and 2018 (Tab. 7). It is a surprising result showing high stability of the taxocene of Harpacticoida in the bay. All these changes in Nematoda were more dramatic and prolonged (Tab. 7) than in Harpacticoida. Structure of the Harpacticoida taxocene is less variable and more stable than of Nematoda taxocene. One of the reasons for this may be more mobility of Harpacticoida than Nematoda and/or better osmoadaptation mechanisms. As was shown, seven species of Harpacticoida live in Crimean waters under salinity higher $100 \mathrm{~g} \mathrm{l}^{-1}$, and six of them at salinity higher than $230 \mathrm{~g} \mathrm{l}^{-1}$ (Anufriieva, 2015). Six of them were found in this study. Some species of Ostracoda also can dwell at salinity more than $250 \mathrm{~g}^{-1}$ (Anufriieva et al., 2019). There are no published data on such a wide halotolerance in Nematoda.

All data above show that the responses of the meiobenthos to the salinity increase in the lagoon are very complicated and cannot be put in one general trend. The salinity changes with the consequent changes in other factors mutually affect the different meiobenthic characteristics. Currently, it is impossible to correctly separate a role of different factors in the meiobenthic structure changes and predict further changes, which may occur in the lagoon meiobenthos. It is necessary to continue monitoring in Bay Sivash to better understand the interrelation of different causes and effects in the transformation of the meiobenthos under a sharp salinity increase.

Acknowledgements. Sampling of benthos in 2018, experiments, data analysis and this manuscript writing was supported by the Russian Science Foundation grant 18-16-00001 (for N. Shadrin, E. Kolesnikova, T. Revkova, E. Anufriieva), the part concerning long-term monitoring before 2018 in Bay Sivash was conducted in the framework of the state assignment of A.O. Kovalevsky Institute of Biology of the Southern Seas of RAS (№ 0556-2019-0011), study of TSS and DOM was supported by the state assignments of Marine Hydrophysical Institute of RAS (№ 0827-2018-0002, 0827-2018-0003). 
Table 7. Calculated pairwise Jaccard and Chekanovski-Sørensen-Dice coefficients of species composition similarity found in bottom community in different years.

\begin{tabular}{|c|c|c|c|c|}
\hline \multirow[t]{2}{*}{ Coefficient } & \multirow{2}{*}{$\begin{array}{l}\text { The threshold values to } \\
\text { make a conclusion } \\
\text { aboutthesimilarity, \% }\end{array}$} & \multicolumn{3}{|c|}{$\begin{array}{l}\text { Calculated values of coefficients } \\
\text { (compared years) }\end{array}$} \\
\hline & & $2013-2015$ & $2013-2018$ & $2015-2018$ \\
\hline \multicolumn{5}{|c|}{ Harpacticoida } \\
\hline Jaccard & 42 & 30 & 50 & $45\left(65^{*}\right)$ \\
\hline Chekanovski-Sørensen-Dice & 59 & 46 & 67 & $63\left(77^{*}\right)$ \\
\hline Number of common species & & 3 & 5 & 5 \\
\hline \multicolumn{5}{|c|}{ Nematoda } \\
\hline Jaccard & 42 & 19 & 24 & $16\left(19^{*}\right)$ \\
\hline Chekanovski-Sørensen-Dice & 59 & 31 & 16 & $28(32 *)$ \\
\hline Number of common species & & 8 & 9 & 5 \\
\hline
\end{tabular}

* - without samples taken at salinity of $30 \mathrm{~g}^{-1}$.

The authors are grateful to Dr. Bindy Datson (Australia) for her selfless work in improving the English of the manuscript.

\section{Conflict of interest}

All authors declare that they have no conflict of interest.

\section{References}

Abdo MH. 2005. Physico-chemical characteristics of Abu Za'baal ponds, Egypt. Egypt J Aquat Res 31: 1-15.

Alves AS, Adão H, Ferrero TJ, Marques JC, Costa MJ, Patrício J. 2013. Benthic meiofauna as indicator of ecological changes in estuarine ecosystems: the use of nematodes in ecological quality assessment. Ecol Indic 24: 462-475.

Anufriieva EV. 2015. Do copepods inhabit hypersaline waters worldwide? A short review and discussion. Chin J Oceanol Limn 33: $1354-1361$.

Anufriieva E, Hołyńska M, Shadrin N. 2014. Current invasions of Asian Cyclopid species (Copepoda: Cyclopidae) in Crimea, with taxonomical and zoogeographical remarks on the hypersaline and freshwater fauna. Ann Zool 64: 109-130.

Anufriieva EV, Kolesnikova EA, Shadrin NV. 2019. Distribution and population dynamics of the highly halotolerant species Eucypris mareotica (Fischer, 1855) (Crustacea, Ostracoda) in hypersaline lakes of Crimea. Inland Water Biol 12: 170-177.

Armonies W. 1988. Physical factors influencing active emergence of meiofauna from boreal intertidal sediment. Mar Ecol Prog Ser 49: 277-286.

Boulion VV, Anokhin LE, Arakelova EU. 1989. Primary production of the hypehaline lakes in Crimea. Trudy Zoologicheskogo Instituta 205: 14-25 (in Russian).

Carrasco NK, Perissinotto R. 2012. Development of a halotolerant community in the St. Lucia Estuary (South Africa) during a hypersaline phase. PloS One 7: e 29927.

Carugati L, Gatto B, Rastelli E, Martire ML, Coral C, Greco S, Danovaro R. 2018. Impact of mangrove forests degradation on biodiversity and ecosystem functioning. Sci Rep 8: 13298.

De Lomas JG, Corzo A, Garcia CM, Van Bergeijk SA. 2005. Microbenthos in a hypersaline tidal lagoon: factors affecting microhabitat, community structure and mass exchange at the sediment-water interface. Aquat Microb Ecol 38: 53-69.

Drapun I, Anufriieva E, Shadrin N, Zagorodnyaya Y. 2017. Ostracods in the plankton of the Sivash Bay (the Sea of Azov) during its transformation from brackish to hypersaline state. Ecol Montenegrina 14: 102-108.

Elloumi J, Carrias JF, Ayadi H, Sime-Ngando T, Boukhris M, Bouaïn A. 2006. Composition and distribution of planktonic ciliates from ponds of different salinity in the solar saltwork of Sfax, Tunisia. Estuar Coast Shelf Sci 67: 21-29.

El-Shabrawy GM, Anufriieva EV, Germoush MO, Goher ME, Shadrin NV. 2015. Does salinity change determine zooplankton variability in the saline Qarun Lake (Egypt)? Chin J Oceanol Limn 33: 1368-1377.

El-Shabrawy GM, Anufriieva EV, Shadrin NV. 2018. Tintinnina (Ciliophora) and Foraminifera in plankton of hypersaline Lagoon Bardawil (Egypt): spatial and temporal variability. Turk $J$ Zool 42: 218-229.

Farkas J, Bådsvik CY, Altin D, Nordtug T, Olsen AJ, Hansen BH. 2017. Acute and physical effects of water-based drilling mud in the marine copepod Calanus finmarchicus. J Toxicol Environ Health A 80: 907-915.

Ferrarin C, Umgiesser G. 2005. Hydrodynamic modeling of a coastal lagoon: the Cabras lagoon in Sardinia, Italy. Ecol Modell 188: 340-357.

Filippov AA, Komendantov AY. 1995. The salinity tolerance of benthic invertebrates of the Aral Sea. Int J Salt Lake Res 4: 251-263.

Gambi C, Totti C, Manini E. 2003. Impact of organic loads and environmental gradients on microphytobenthos and meiofaunal distribution in a coastal lagoon. Chem Ecol 19: 207-223.

Ghale YA, Altunkaynak A, Unal A. 2018. Investigation anthropogenic impacts and climate factors on drying up of Urmia Lake using water budget and drought analysis. Water Resour Manag 32: 325-337.

Giere O. 1993. Meiobenthology: the microscopic fauna in aquatic sediments. Berlin: Springer-Verlag, 328 p.

Golubkov SM, Shadrin NV, Golubkov MS, Balushkina EV, Litvinchuk LF. 2018. Food chains and their dynamics in ecosystems of shallow lakes with different water salinities. Russ $J$ Ecol 49: 442-448.

Gyedu-Ababio TK, Baird D. 2006. Response of meiofauna and nematode communities to increased levels of contaminants in a laboratory microcosm experiment. Ecotoxicol Environ Saf 63: 443-450. 
Jones E, Qadir M, van Vliet MTH, Smakhtin V, Kang SM. 2019. The state of desalination and brine production: A global outlook. Sci Total Environ 657: 1343-1356.

Jordan TE, Cornwell JC, Boynton WR, Anderson JT. 2008. Changes in phosphorus biogeochemistry along an estuarine salinity gradient: The iron conveyer belt. Limnol Oceanogr 53: 172-184.

Kolesnikova EA, Anufriieva EV, Latushkin AA, Shadrin NV. 2017. Mesochra rostrata Gurney, 1927 (Copepoda, Harpacticoida) in Sivash Bay (Sea of Azov): Is it a new alien species or a relict of Tethys? Russ J Biol Invasions 8: 244-250.

Kolesnikova EA, Mazlumyan SA, Shadrin NV. 2008. Seasonal dynamics of meiobenthos fauna from a salt lake of the Crimea, in The Firth International Conference of Environmental Micropaleontology, Microbiology and Meiobenthology (EMMM), Chennai, India, $155-158$.

Levin LA, Ekau W, Gooday AJ, Jorissen F, Middelburg JJ, Naqvi SWA, Zhang J. 2009. Effects of natural and human-induced hypoxia on coastal benthos. Biogeosciences 6: 2063-2098.

Lockwood D. 2019. Lakes and rivers are getting saltier. ACS Cent Sci 5: 376-379.

López-González PJ, Guerrero F, Castro MC. 1997. Seasonal fluctuations in the plankton community in a hypersaline temporary lake (Honda, southern Spain). Int J Salt Lake Res 6: 353-371.

Mageed AAA. 2006. Spatio-temporal variations of zooplankton community in the hypersaline lagoon of Bardawil, North Sinai, Egypt. Egypt J Aquat Res 32: 168-183.

Mayer TD, Pilson SL. 2019. Interactions of water levels with water quality, endemic waterbirds, and invasive species in a shallow, tropical pond. Hydrobiologia 829: 77-93.

Micklin P, Aladin NV, Plotnikov I. 2016. Aral Sea. Berlin: SpringerVerlag, $453 \mathrm{p}$.

Mokievsky VO. 2009. Quantitative distribution of the meiobenthos in the Large Aral Sea in 2003 and 2004. J Mar Syst 76: 336-342.

Mokievsky VO, Miljutina MA. 2011. Nematodes in meiofauna of the Large Aral Sea during the desiccation phase: taxonomic composition and redescription of common species. Russ J Nematol 19: 31-43.

Moreno M, Ferrero TJ, Gallizia I, Vezzulli L, Albertelli G, Fabiano M. 2008. An assessment of the spatial heterogeneity of environmental disturbance within an enclosed harbour through the analysis of meiofauna and nematode assemblages. Estuar Coast Shelf Sci 77: 565-576.

Müller PH, Neuman P, Storm R. 1979. Tafeln der mathematischen statistik. Leipzig: VEB Fachbuchverlag, 272 p.

Ólafsson E, Carlström S, Ndaro SG. 2000. Meiobenthos of hypersaline tropical mangrove sediment in relation to spring tide inundation. Hydrobiologia 426: 57-64.

Pesenko JA. 1982. Principles and methods of quantitative analysis in faunal studies. Moscow: Nauka, 287 p. (in Russian).

Plotnikov IS. 2016. Long-term changes of the fauna of free-living aquatic invertebrates in the Aral Sea. St. Petersburg: ZIN RAS, 168 p. (in Russian)

Riera R, Tuya F, Sacramento A, Ramos E, Rodríguez M, Monterroso Ó. 2011. The effects of brine disposal on a subtidal meiofauna community. Estuar Coast Shelf Sci 93: 359-365.

Schallenberg M, Burns CW. 2003. A temperate, tidal lake-wetland complex 2. Water quality and implications for zooplankton community structure. New Zeal J Mar Fresh 37: 429-447.
Segal RD, Waite AM, Hamilton DP. 2006. Transition from planktonic to benthic algal dominance along a salinity gradient. Hydrobiologia 556: 119-135.

Semprucci F, Frontalini F, Sbrocca C, du Chatelet EA, Bout-Roumazeilles V, Coccioni R, Balsamo M. 2015. Meiobenthos and free-living nematodes as tools for biomonitoring environments affected by riverine impact. Environ Monit Assess 187: $1-19$.

Sergeeva NG, Shadrin NV, Anufriieva EV. 2019. Long-term changes (1979-2015) in the nematode fauna in Sivash Bay (Sea of Azov), Russia, worldwide the largest hypersaline lagoon, during salinity transformations. Nematology 21: 337-347.

Shadkam S, Ludwig F, van Oel P, Kirmit Ç, Kabat P. 2016. Impacts of climate change and water resources development on the declining inflow into Iran's Urmia Lake. J Great Lakes Res 42: 942-952.

Shadrin N. 2018. Hypersaline lakes as the polyextreme habitats for life, in Zheng M, Deng T, Oren A (Eds.), Introduction to salt lake sciences. Beijing: Science Press, pp. 180-187.

Shadrin NV, Anufriieva EV. 2013. Climate change impact on the marine lakes and their Crustaceans: The case of marine hypersaline Lake Bakalskoye (Ukraine). Turk J Fish Aquat Sci 13: 603-611.

Shadrin NV, Anufriieva EV. 2018. Ecosystems of hypersaline waters: structure and trophic relations. Zh Obshch Biol 79: 418-427 (in Russian)

Shadrin NV, Anufriieva EV, Kipriyanova LM, Kolesnikova EA, Latushkin AA, Romanov RE, Sergeeva NG. 2018. The political decision caused the drastic ecosystem shift of the Sivash Bay (the Sea of Azov). Quat Int 475: 4-10.

Shadrin N, Litvinchuk L. 2005. Impact of increased mineral particle concentration on the behavior, suspension-feeding and reproduction of Acartia clausi (Copepoda), in Dame RF, Olenin S (Eds.), The comparative roles of suspension-feeders in ecosystems. Dordrecht: Springer, pp. 137-146.

Shen TJ, Chao A, Lin CF. 2003. Predicting the number of new species in further taxonomic sampling. Ecology 84: 798-804.

Soloveva OV, Tikhonova EA, Alemov SV, Burdiyan NV, Viter TV, Guseva EV, Kotelyanets EA, Bogdanova TA. 2019. Ecological state of the southeastern part of Sivash Bay (Sea of Azov) under conditions of changing salinity. Contemp Probl Ecol 12: 179-188.

Suzuki MS, Ovalle AR, Pereira EA. 1998. Effects of sand bar openings on some limnological variables in a hypertrophic tropical coastal lagoon of Brazil. Hydrobiologia 368: 111-122.

Telesh IV, Khlebovich VV. 2010. Principal processes within the estuarine salinity gradient: a review. Marine Poll Bull 61: 149-155.

Velasco J, Millán A, Hernández J, Gutiérrez C, Abellán P, Sánchez D, Ruiz M. 2006. Response of biotic communities to salinity changes in a Mediterranean hypersaline stream. Saline Syst 2: 12.

Vorobyev VP. 1940. Hydrobiological essay on the Eastern Sivash and its potential for fisheries. Proc AzCherNIRO 12: 69-164 (in Russian).

Zeppilli D, Leduc D, Fontanier C, Fontaneto D, Fuchs S, Gooday AJ, Goineau A, Ingels J, Ivanenko VN, Kristensen RM, Neves RC. 2018. Characteristics of meiofauna in extreme marine ecosystems: a review. Mar Biodivers 48: 35-71.

Zulkifly S, Hanshew A, Young EB, Lee P, Graham ME, Piotrowski M, Graham LE. 2012. The epiphytic microbiota of the globally widespread macroalga Cladophora glomerata (Chlorophyta, Cladophorales). Am J Bot 99: 1541-1552.

Cite this article as: Shadrin N, Kolesnikova E, Revkova T, Latushkin A, Chepyzhenko A, Drapun I, Dyakov N, Anufriieva E. 2019. Do separated taxa react differently to a long-term salinity increase? The meiobenthos changes in Bay Sivash, largest hypersaline lagoon worldwide. Knowl. Manag. Aquat. Ecosyst., 420, 36. 